\title{
Traveling Houses: Performing Diasporic \\ Relationships in Europe
}

\author{
A-Chr (Tina) Engels-Schwarzpaul
}

Far from home, Pacific houses not only perform and enact Pacific identities in global scenic spaces such as theme parks or museums but, over time, also produce new identities and relationships in trans- or bi-local constellations. ${ }^{1}$ Surprisingly, starting in the nineteenth century, quite a number of such houses traveled to Europe and the United States, mostly from Aotearoa/New Zealand and Sāmoa. The first traveling wharenui (great or meeting house), Mataatua, was removed from Whakatāne in I 879, against significant resistance, and transported to an exhibition in Sydney in I880 (Mane-Wheoki I993; Allen 1998). Mataatua was subsequently embezzled by New Zealand's colonial administration and sent to London, to finally return home more than a century later, in I996. All other Māori houses leaving Aotearoa before World War I (Ruatepupuke II from Tokomaru, Hinemihi o te Ao Tawhito from Te Wairoa, and Te Wharepuni a Maui and Rauru, both from Rotorua) are likely to stay in their current locations-the Field Museum (USA), Clandon Park (UK), Stuttgart's Linden Museum (Germany), and the Hamburg Museum für Völkerkunde (Germany), respectively. Samoan fale (houses) traveled to the I 893 World's Columbian Exhibition in Chicago, the I924 British Empire Exhibition at Wembley, and the 1925 New Zealand and South Seas International Exhibition in Christchurch. In the I970s, a cluster of Samoan fale were included in the construction of the Little World Museum of Man in Aichi, Japan, and, in 2004, a fale from Apia arrived at the Tropical Islands Resort in Brand, Germany (figure I). At the Polynesian Cultural Center in Lā'ie, Hawai' $i$, both wharenui and fale have offered edutainment to locals and tourists as tokens of the exotic since I963, but they also maintain, in their own ways, traditional as well as everyday cultural practices.

How well these houses have been able to establish themselves in their

The Contemporary Pacific, Volume 29, Number I, 38-64

(C) 2017 by University of Hawai' $i$ Press 


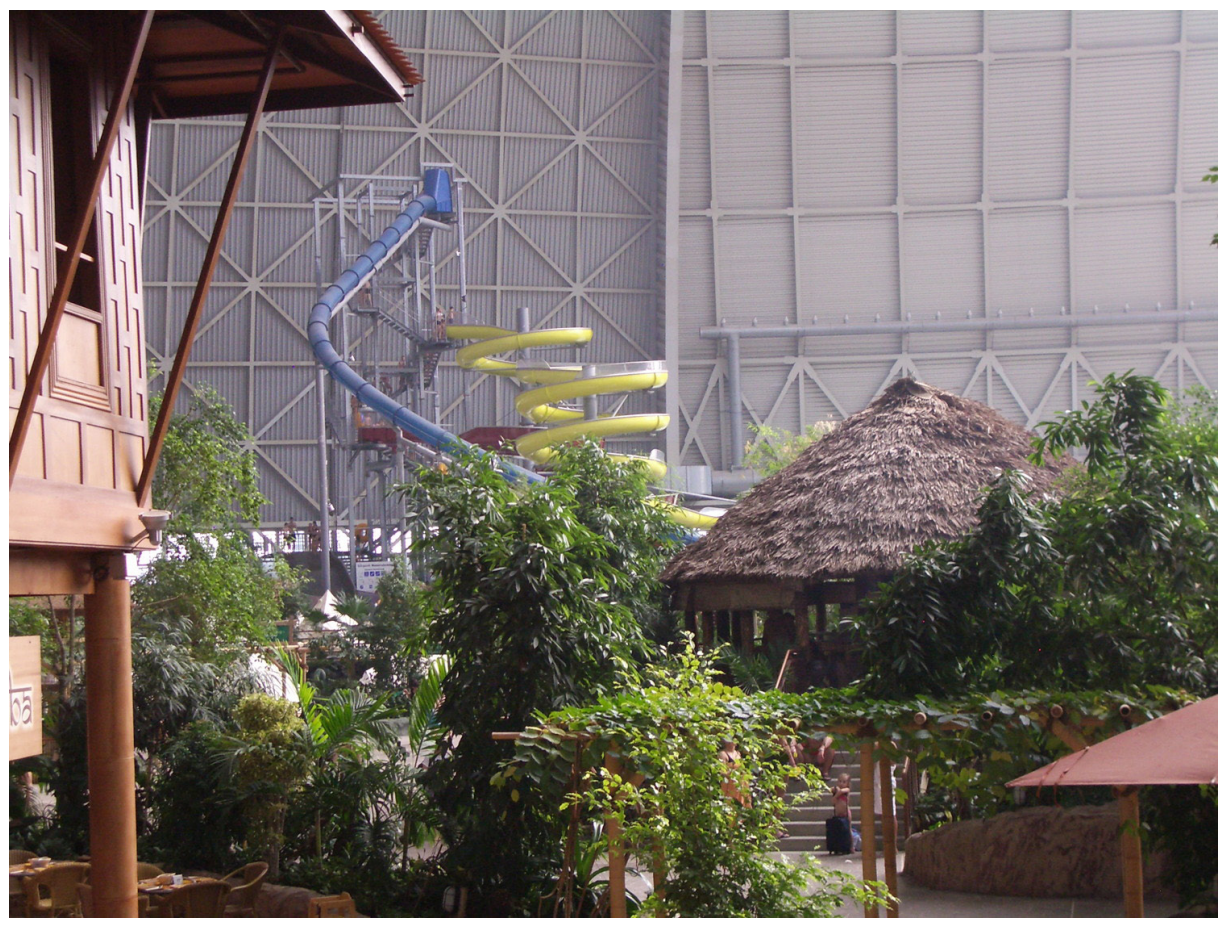

Figure I The Samoan fale at Tropical Islands, next to Thai Pavilion (left front), and "Germany's highest water slide" (left back), Brand, Germany. Photo by author, 2008 .

new locations varies considerably, and success or failure seems to depend significantly on the degree to which the houses are connected with both their source communities and new local ones. The house with the most vibrant presence abroad must be, on several counts, Hinemihi in London. The focus of a strong and lasting relationship between the London Māori expatriate community (Ngāti Rānana), her source community (Ngāti Hinemihi/Tūhourangi), the UK National Trust, and other local supporters, Hinemihi has functioned as a marae (communal and sometimes sacred meeting place) for many years now. New types of relationships and new protocols of use have been developed, as well as a future-oriented conservation strategy (see Wikitera 20I 5, 228-229).

In this article I explore, from both Pacific and European theoretical perspectives, ${ }^{2}$ the conditions under which Pacific houses performatively create and aggregate relationships in the European diaspora, often indexing the latter's ambivalent or multivalent nature. This constellation of 
scholarship offers the possibility of tacking back-and-forth between distinct perspectives that come into and out of view as Pasifika structures travel in time and space. ${ }^{3}$

Both at home and abroad, some types of performance are more likely to succeed than others, and some of the ways in which these traveling houses have been re-localized are more supportive of authenticity, relationships, and sustainability than others.

\section{A MĀori AmbASSADOR}

Rāuru Wharenui Celebrates Ioo Years (Parahi 20I2), a documentary uploaded to YouTube on I 2 November 20I2, opens with Baroque music and outdoor shots of a rainy Northern European city before it cuts to the interior of Rauru wharenui. The narrator tells the story of the house's origins and travel: today located at the Museum für Völkerkunde in Hamburg, Germany (figures 2a and 2b), Rauru was built in Rotorua, New Zealand, in I900 and was later "controversially sold" (Parahi 20I2). While Rauru has stood "transfixed" in the museum since his travels finally ended in I9I2, his people were on the move: successive Māori groups and individuals came to visit after World War II. They introduced new meanings, values, and processes into the curatorial process at the museum. Finally, on Rauru's one hundredth anniversary in Hamburg, a party of his descendants led by Mauriora Kingi performed prayers and songs in front of a select but sizeable group of invitees. Life was "returned to his old bones through ... the long overdue ceremonies of his people," ensuring that Rauru can hear and see that "Māori culture is still alive" (Parahi 20I 2, I:OO-I:5 5 mins). ${ }^{4}$

For his part, museum director Wulf Köpke declared the relationship between Rauru and the museum not a legal but "a spiritual matter" (Parahi 20I 2, 4:48-6:2 I mins). Rebutting Te Poroa Malcolm—a Te Arawa elder who said that he appreciates the care the museum has given Rauru but, nevertheless, believes that Rauru should return to New Zealand to his people (Parahi 20I2, 5:43-47 mins)—Köpke argued, "We are the caretakers of the house ... and so they would have to accuse us of neglecting that." Asked whether he would be prepared to relinquish Rauru, the director responded, "No, no, we shouldn't . . . the spirits of Rauru will make up their mind. If they want to stay here, they will stay, and if they decide that they won't, the house will go back.... We shouldn't reduce it to a legal matter ... it's a spiritual matter" (Parahi 20I 2, 4:48-6:2 I mins). 


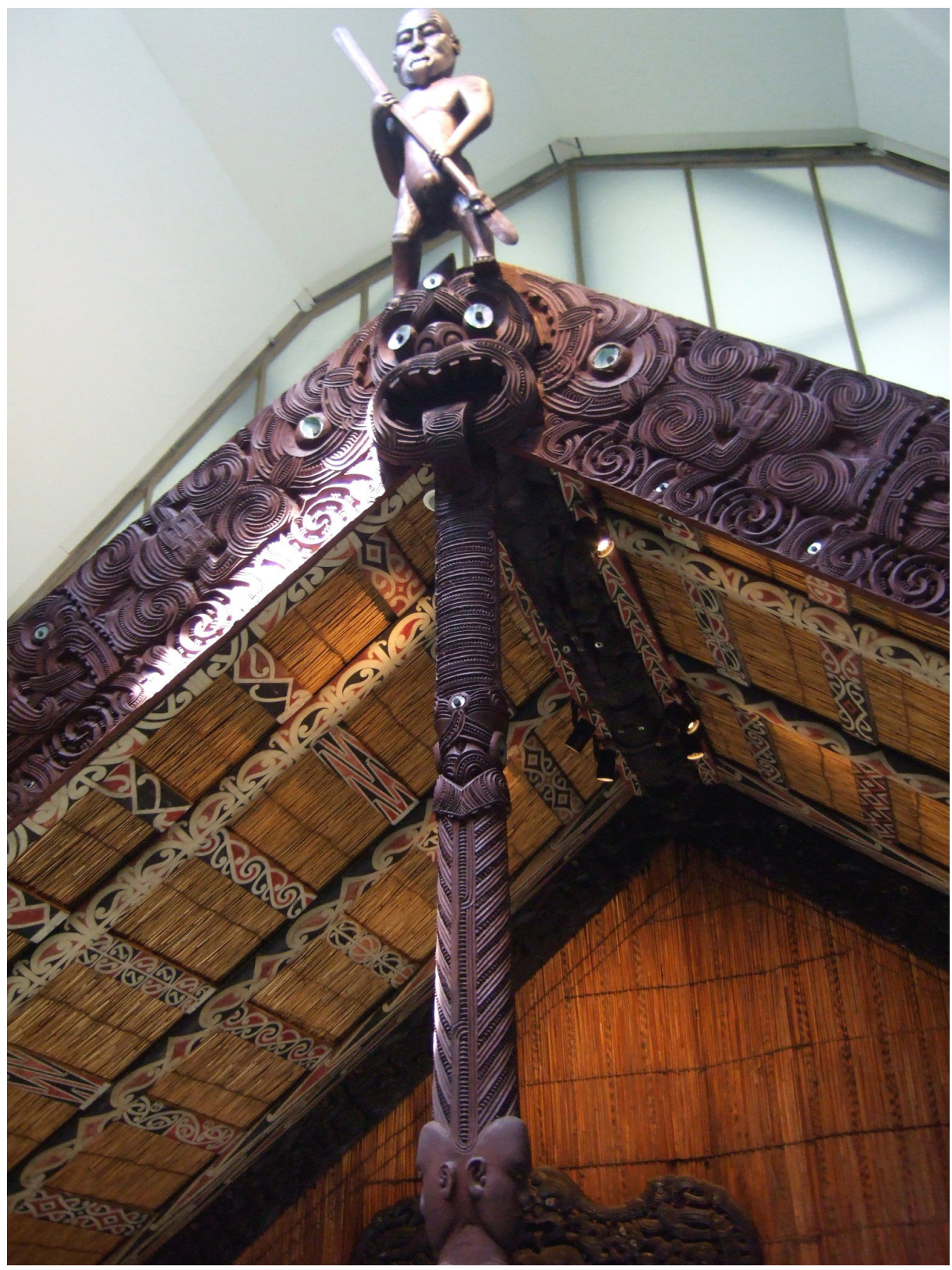

FIGURE 2a Rauru after restoration and redesign of the now well-lit exhibition space in the Museum für Völkerkunde, Hamburg, Germany. Photo by Margret Pirzer, 2013. Creative Commons License: https://www.flickr.com/photos/ 57703761@No6/947I09396r/in/album-72I57634780971866/ 


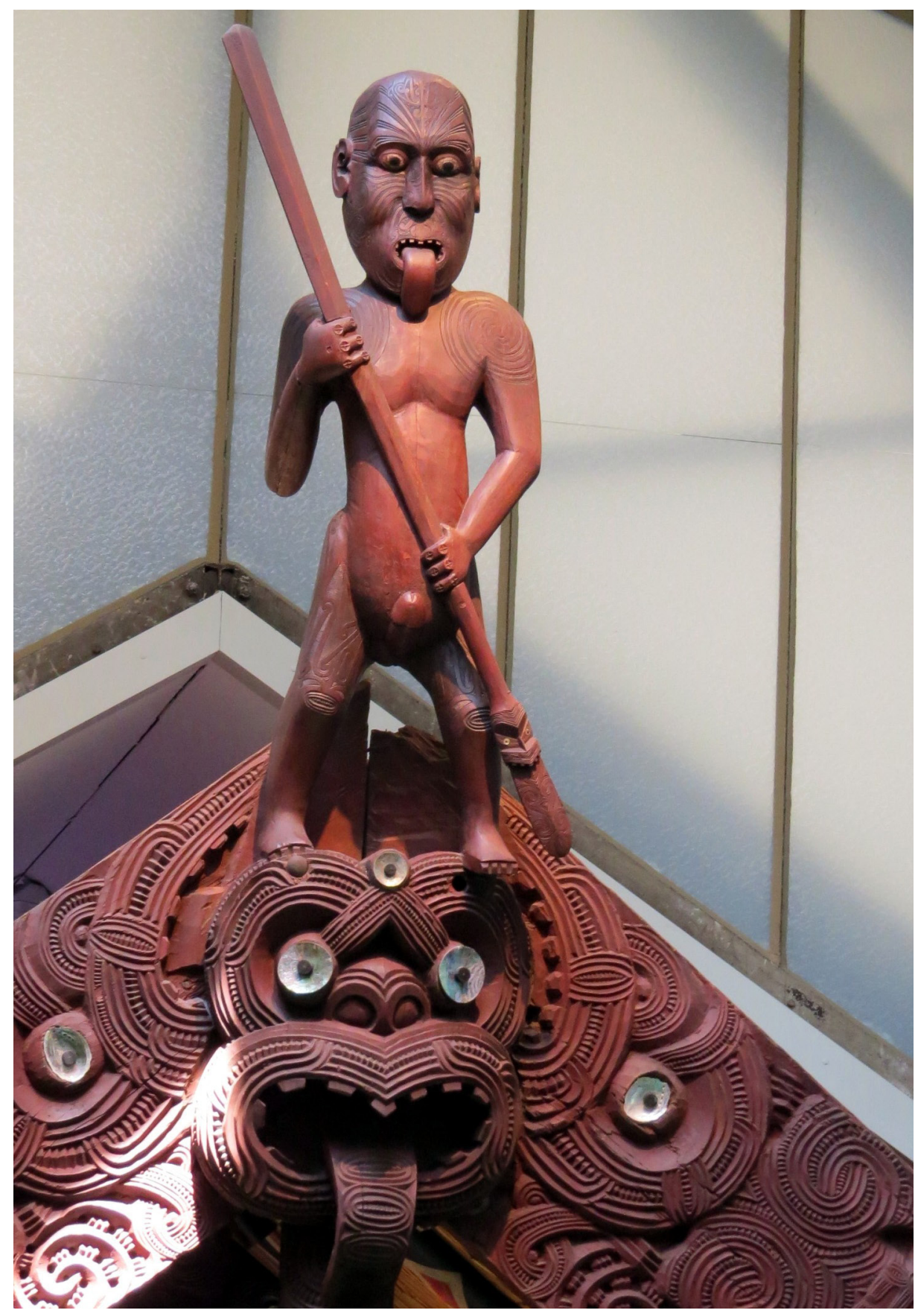

FIgure 2 b Rauru, detail of tekoteko (carved human figure). Photo by Margret Pirzer, 20I3. Creative Commons License: https://www.flickr.com/photos/ 5770376I@No6/9473874242/in/album-72I5763478097I866/ Note: Rauru is difficult to capture due to the unusual proportions of the exhibition space. More photos are available on the Hamburg Museum für Völkerkunde website: http://maori-hamburg.de/de/bilder-rauru.html 
Walter Benjamin, a German Jewish philosopher and cultural critic writing in the early twentieth century (about, for example, the relationship between official and subdued history, or the history of victor and oppressed [Benjamin I969a]), might have described this line of argument-most likely an effect of successive Māori delegations' engagement with the museum-as a new partition in a field of historical perception. Through a "displacement of the angle of vision," a positive component can arise from an "initially excluded, negative component" (Benjamin I999, 459 $\left.\left[\mathrm{NIa}_{3}\right]\right)$. By that he would mean that, as successive displacements partition perception in new ways, more and more of the past is brought into the present in a generative and permanent historical restitution. In Rauru's case, a past then becomes visible that never before seemed to exist in the history of house, present guardians, and original community. And an important aspect of this past-the relational web in which the wharenui is embedded-points toward a fundamental difference concerning relationships of exchange in Pacific and Western contexts. While most types of exchange in Western modernity isolate objects from their local and relational contexts so that they may circulate freely, many Pacific views of exchange relationships are generative and reciprocal (Tapsell 1997). Accordingly, it appears that Māori (or Te Arawa) delegations' repeated performance of identity, during visits at the museum since the I970s or I980s, has impacted all parties' angles of vision, so that the Hamburg museum staff can recognize new aspects in the history of their relationship with Rauru. This would explain, for example, Köpke's invocation of Rauru's spirits-hardly the type of rhetoric to be expected from German museum directors in the past. Also unusual, at least for a European audience, would be his and curator Jeanette Kokott's use of the personal pronoun "he" when speaking of Rauru. This change in language is part of modifications at a global level, beyond the Hamburg museum: Hinemihi o te Ao Tawhito is likely to have been the first to be addressed as a person by a European institution, the UK National Trust (her legal owner).

The intensifying relationships between Te Arawa visitors, the Hamburg museum staff, and Rauru's source community in Aotearoa moved Rauru out of his isolation, particularly during the restoration project leading up to the one hundredth anniversary of his residence in the museum. By comparison, Te Wharepuni a Maui's situation in Stuttgart is less clear, since the Linden Museum kept the house in storage during a long-term museum renovation. Finally, the Samoan fale at the Tropical Islands Resort, fol- 
lowing a reasonably promising beginning in 2004 and an initial period of palpable presence, has fallen into forgetfulness-but more about this later.

The individual fates of these Pacific houses are enmeshed in a global context that has changed significantly since they departed from their homelands (mostly) under colonial rule. Global decolonization movements, and the postcolonial debates accompanying them, altered the relationships in which the houses are embedded, both in the Pacific and in Europe. When Māori groups began visiting Hinemihi and Rauru after World War II, for instance, they had rigorously asserted their rights in protests and tribunal hearings at home-against a state already found repeatedly in breach of the nation's founding treaty-and instigated considerable changes in Aotearoa. However, in comparison with the situation in Sāmoa, which became officially independent in 1962, postcolonialism in Aotearoa/New Zealand is a concept rather than a reality: the colonial settlers' descendants still constitute the country's majority and continue to dominate its politics. This difference (between the Third World and the Fourth World, according to one terminology) seems to be manifested in different attitudes toward tangible and intangible cultural heritage generally and, more specifically, in people's relationship with traditional houses. ${ }^{5}$ Thus, the names of houses are crucial for providing references to the respective ancestors and, very often, their carvers are known. It is significant in the current context that both Hinemihi and Rauru were built by the same master carver, Tene Waitere, to whom at least two members of the successive delegations from Te Arawa are related. Beginning in the r980s, postcolonial aspects of "new museology" also led to a reorientation on the part of the European owners of Pacific houses and to a more reflective stance on the part of curators regarding the centrality of collections and their relationships with communities. Importantly, the source communities of collected artifacts became visible, and museums developed an interest in voices that had previously been unheard (Frazon 2016). These developments, in turn, are likely to have influenced the reception of Māori groups when they began to visit Hinemihi and Rauru in the I980s.

At a dawn ceremony, during the first visit by a delegation from Rotorua since Rauru was first put on display at the museum in I9I $2,{ }^{6}$ the visitors assured the museum that the descendants of the original owner of some of the carvings included in the house did not intend to ask for Rauru's repatriation. Since this first visit, several groups came to visit, including Māori scholar Hirini Moko Mead (probably in 1984); Māori Party co-leader Te Ururoa Flavell (2007); and master carver and sculptor Lyonel Grant 
(2008). A 20I0 visit by Katerina Pihera (of Te Arawa and Ngāti Rangiwewehi descent) and Rangitiaria Tibble (of Te Arawa and Ngāti Whakaue descent) seems to have turned the tide in the relationships between Rauru's keepers and the museum staff. Curator Jeanette Kokott commented that the "resultant contact with the community from which Rauru came was important to the museum, and it proved to be a lasting relationship" (20I2, 30)..$^{7}$ On the opening night of Rauru's hundredth anniversary in Hamburg, the Te Arawa delegation signed an agreement with the city of Hamburg. It made Rauru a tūrangawaewae (place of belonging) for Māori and all New Zealanders, as well as an official meeting place for the New Zealand government. Māori visitors are entitled to sleep in the house and New Zealanders to visit the museum gratis. Köpke expects Rauru to play an active role in representing Māori culture in Europe, and he has adopted the "ambassador" terminology that Julie Lawlor (UK National Trust property manager) had already used in a 2006 Statement of Significance about Hinemihi, following discussion with Ngāti Rānana. ${ }^{8}$

This surely constitutes a change from a regime under which Māori and Pacific houses were "controversially" sold to be shipped overseas as ethnographic artifacts, mementos, or museum specimens.

\section{Home Away from Home}

Whare and fale signal, at least at first sight, a place-based existence. The words are significantly used in the terms whare tangata (Māori: womb) or falefale (Samoan: placenta); their synonyms, whenua and fanua, designate land. For Māori, "the tribe's whare tupuna, which," in Paul Tapsell's region, "is an elaborately carved eponymous ancestor, is deemed to be the ultimate taonga [prized heirloom] of the people, because it brings both physical and spiritual authority to the marae on which it rests" (Tapsell 2002, I43). ${ }^{9}$ On the other side of the world, Benjamin called houses "man's companions since primeval times," not only fulfilling a lasting human need for physical shelter but also serving as "living force[s]" (1969b, 239), shaping and sheltering the relationships unfolding under their roofs as much as those with the world outside.

If people, houses, and land are so intricately related, the question arises as to what happens when Pacific people and houses travel (see Allen I998, I 48-I49). Until the late twentieth century, a striking aspect of these travels was that houses and people typically did not travel together: on the one hand, people traveled without houses and, on the other, houses without 
people (see, eg, Mane-Wheoki 1993, 35). The first documented case of Samoan traveling fale, at the 1893 World's Columbian Exposition in Chicago, involved a Samoan village including a fale that Harry J Moors, the impresario, attributed to former paramount ruler Mata'afa Iosefo. The "Samoan" performance troupe accompanying it, however, consisted in reality of Pacific Islanders whom Moors had picked up on his voyage to the United States. Following shocking experiences with the treatment of Samoans by another impresario, Robert Cunningham, the Samoan government had decided "that native Samoans would not be permitted to join him" (Samoa Times and South Sea Advertiser I 893). The two other Māori wharenui also traveled from Aotearoa to Europe unaccompanied. Hinemihi left in I88I, and Rauru spent years en route-on ship, at customs, and in storage somewhere in Hamburg-before he was received by the Hamburg Museum für Völkerkunde in I9I2 (Triesch 20I2). After an odyssey lasting more than four decades, at the I924 British Empire Exhibition in Wembley, Mataatua eventually flanked the classicist New Zealand Pavilion. On the other side stood a Samoan fale specifically commissioned for the exhibition in Mulinu'u, Upolu, by the New Zealand colonial government. In both cases, the New Zealand government had rejected Samoan and Māori proposals to accompany their houses for fear of "the unsettling and bad after-effects which invariably follow on the return of the participants" of "Native troupes." 10

On the other hand, Samoans performed in European nineteenth and early twentieth century Völkerschauen (ethnographic shows) in zoological gardens, in "villages" surrounded by palm trees. Sometimes, a village was simply represented on a painted backdrop, but usually houses were made up from parts or materials (or both) that had been shipped from their original locations, or even from local materials that vaguely looked like the spectators' idea of tropical houses. Contemporary photos taken in Hamburg and Frankfurt show that the buildings had little in common with Samoan fale-except for some iconic elements like thatched roofs and pola (blinds used to close a fale temporarily). ${ }^{11}$

Visitors strolled through the villages and vicariously participated in "real-life" activities. An emphasis on everyday craft production, cooking, child rearing, and other domestic activities produced a noa (secular) space, in which tapu and mana (the sacred, prestige and power) had no place. Wharenui and fale tele (meeting houses) would have been inappropriate for these purposes. The emphasis on the mundane aspects of Samoan life also made it easy to pass over the fact that some participants were high- 
ranking politicians, known by name and entertained by influential members of society (Dreesbach 20I2), who had come to Germany partially on a diplomatic mission. Völkerschauen were successful when the audience members were able to make connections between (what they imagined to be) the exotic strangers' lives and elements of their own (Dreesbach 20I2, I4, I49). Accordingly, "authentic" ensembles of original shelters, tools, and means of transport showed families "in their native villages, wearing their traditional clothing, and engaging in their customary ways of eating, dancing, etc." (Jonassohn 200I).

The audience's ideas of "native life" would have been formed in part by posters advertising the shows; there was "remarkable correspondence between the stereotypes called up in the advertisements and the [on-site] enactment" (Dreesbach 20I2, I60). For instance, a poster advertising a I9I0 "Samoa" show (the year in which Rauru was purchased by the museum) shows two brown-skinned, muscular men in short grass skirts carrying a pig to a banquet held in a village (Dreesbach 20I 2, I 4O-I4 I). ${ }^{12}$ The assemblages of houses, palm trees, tools, household items, boats, and the performers themselves successfully produced exotic atmospheres and spectacular scenes in which people dwelt "just like us"-yet differently. A "staged authenticity" (MacCannell I989, 2008) was produced connoting the South Seas to a German public. Importantly, though less obvious to European writers, these assemblages may also have re-presented their home to the Samoan performers and provided opportunities to refocus or rethink identities and relationships.

This brings us finally to Hinemihi o te Ao Tawhito (figure 3), who arrived without her people in London but is today surrounded by an extended and diverse community. Keri-Anne Wikitera's $2015 \mathrm{PhD}$ thesis gives a detailed account of the departure and arrival in London of this whare tūpuna (ancestral house), ${ }^{13}$ two decades earlier than Rauru came to Hamburg and under less controversial circumstances (however, see Wikitera 20I 5, 3I, 35 for disagreements or confusion over Hinemihi's use and sale). Hinemihi was built in I88I at Te Wairoa, close to the famous Pink and White Terraces in Aotearoa, and sold to Lord Onslow after the eruption of Mount Tarawera in I 886. Onslow, retiring governor-general of New Zealand, took her home as a souvenir to the United Kingdom in I 892. Ever since, the whare has stood in Clandon Park (Surrey), where-as the story goes-convalescing Māori soldiers discovered her during World War I. After World War II, Hinemihi increasingly provided a "home away from home" for Ngāti Rānana, the Māori expatriate community in Lon- 
don. Compared with Rauru, Hinemihi is well visited by her people, and this connection is likely responsible for explicit shifts in local conservation theories and practices in the United Kingdom. ${ }^{14}$ However, once the links with a source community are broken, as they were in Hinemihi's case for the best part of her stay in Clandon Park, their restoration is complex and often fraught with misunderstandings (see Wikitera 20I5, 2I7). On the whole, it seems, Māori accept such growing pains as part and parcel of the development of better relationships. Hinemihi has been used as a functioning marae since 1995 , and the UK National Trust is currently collaborating on a heritage conservation project with Ngāti Hinemihi, Ngāti Rānana, and Māori architect Anthony Hoete to change Hinemihi into a living house in which meetings can be held and people can sleep. The project develops the relationships between "Hinemihi's people" (Sully, Raymond, and Hoete 20I4; Raymond and Sully 20IO) and makes her part of Māori lives in the diaspora. This Māori (re)appropriation has "created a new profile for Hinemihi both in the UK and New Zealand through which she has been re-imbued with a Mãori physical and spiritual presence" (Sully, Raymond, and Hoete 20I4, 2 I0). She has become "a Maori Ambassador at the centre of a transcultural partnership between British people and New Zealanders, Maori and non Maori," and this partnership will hopefully see to her transformation "from a vulnerable historic building into an active marae (Maori ceremonial space) and a cultural centre for Maori activities and learning in Britain" (Te Maru o Hinemihi 20I6). ${ }^{15}$

Hinemihi's reappropriation by Ngāti Rānana and Ngāti Hinemihi/ Tūhourangi shows several factors that contribute to creating a new home for a traveling Pacific house: the ongoing relationship between the whare tūpuna and his or her whakapapa whānau (the kin-based source community/family); the existence of an interested local kaupapa whānau (a non-kin-based community/family of interest); and a relationship between them that admits different approaches and flexible interpretations. Part of this local kaupapa whānau is also her legal owner, the UK National Trust, whose representatives see their role as joint caretakers (Wikitera 2015, 2I3-2I4).

Over the last decades, Pacific houses traveling overseas have tended to be accompanied by some of their people, often the (master) builders who produced them, usually on commission. An early example of this trend are the Samoan fale and Māori whare built at the Polynesian Cultural Center (PCC) in Lā'ie, Hawai'i, run by the Church of Jesus Christ of Latter Day Saints (LDS). The Māori wharenui was largely built in Hamilton, Aotea- 
roa, and reassembled by a small group of Māori on site in 1963. Later, I 48 LDs labor missionaries not only helped with the finishing touches but also performed as Te Aroha Nui o te Iwi Māori, the name also given to the wharenui in the Māori village. The Samoan fale appear to have been built on-site by Samoan labor missionaries in the same year. Like the other Pacific houses at the PCC, whare and fale have continuously been attended by local Māori and Samoan residents, as well as visitors, and also performers from other Pacific Islands present at the PCC. Despite evident problems due to its intensively commercial orientation, the PCC still manages to maintain a certain amount of space for the performance of diasporic relationships within the individual groups and between them (Wineera 2000).

In Europe, a Samoan fale was commissioned in 2004 for the Tropical Islands Resort, close to Berlin, in Germany. Here, too, the beginnings were promising insofar as house and people set out on the journey together.

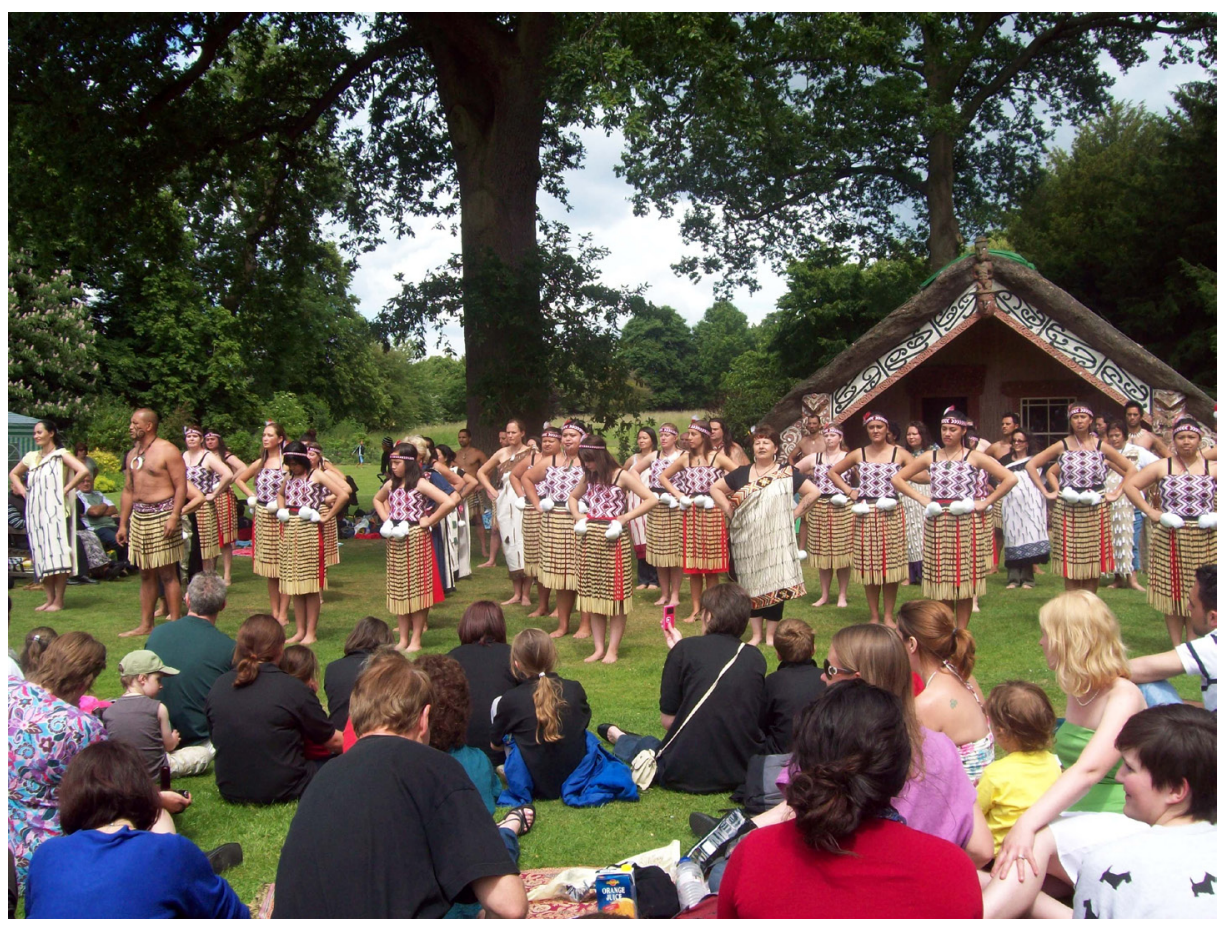

Figure 3 Pōwhiri (welcoming ceremony) at Hinemihi o te Ao Tawhito, Clandon Park, Surrey, England. Photo by Keri-Anne Wikitera, 2009; reproduced with permission. 
This was partially due to the quality standards the commissioner, Malaysian multimillionaire Colin Au, wanted to apply to his project: everything was to be authentic-partially because he believed he knew that this was what the Germans wanted. Produced in Apia, and later assembled by Samoan tufuga (master builders) at the Tropical Village of the resort, the smallish fale was accompanied by dignitaries and a performance troupe to be consecrated in an opening ceremony. The Samoan Tourism Authority (STA), who had brokered the deal, expected ongoing relationships with the resort and regularly recurring performance contracts. Due to the decision to abandon shows performed by overseas troupes, following a 2006 operational review prompted by bad business performance and Colin Au's resignation, these expectations did not come to fruition. As a consequence, the Apia fale was left behind: first, by the tufuga, pastor, and officials who had departed after the opening, and then, at the end of their contract in late 2005 , by the Samoan performers who had kept it company for a while. Reduced to an artifact or a mere object of curiosity, the fale fell into oblivion at the resort: by 2007 , resort visitors I talked to were unaware that there even was a Samoan fale at the resort. In 2008, the originally consecrated and exclusive fale was renamed Kalmoa Cocktail Lounge and turned into a smoking lounge and part-time bar by planners who assumed that visitors did not care about authenticity in people, performances, and buildings.

Samoan performers whom my colleague Albert Refiti and I interviewed in Sāmoa and New Zealand in 2008, on the other hand, usually wanted to maintain relationships with Germany, even though their working conditions had been extremely problematic. Performers told stories of "hanging out" at the fale when they were homesick, which is reminiscent of the companionship role attributed to houses by Benjamin. In 2009, I conducted a second interview in Apia with former sTA manager Sala Pio Tagiilima, who expressed disappointment about the way things at Tropical Islands Resort had developed. Speaking of a "sense of ownership," and seeing that "things that are not being done well, especially with the Samoan fale," he said that it all made him "feel very sad and sometimes hurt." He considered the use of the fale as a smoking lounge "an insult" but was still willing to consult with the resort management about better ways of using the house in ways compatible with fa'a Sāmoa (Samoan way of life). One member of the original performance troupe later returned to Tropical Islands to join his partner in Germany. Esau now works as a bartender, looking out over the "South Sea," a bathing area with an "Island Stage" 
for evening shows, featuring a sand beach. In a 2013 television documentary, Esau did not mention the fale but highlighted how the palm trees were meant "to make things look authentic" (von Mangoldt and Gromes 20I3, II:00 mins). According to the documentary makers (pers comm, January 20I6), Esau was probably aware of the paradoxical nature of his involvement in making things look "real" for a German imagination of the South Seas (Südsee; in real terms, the geographical area of the Pacific).

\section{The Power of Relationships}

When Pacific people and their houses are separated, their respective states of being change both conceptually and experientially. This is more visible in the case of Māori wharenui overseas than for Samoan fale. Perhaps Māori, with their more extended and sustained experience of colonization and alienation from land and taonga, make a clearer conceptual distinction between a wharenui as tūpuna (ancestor) or taonga on the one hand and as an artifact or commodity on the other. Yet neither of these conceptual pairs are exclusively either/or propositions nor does change occur in only one direction. "The life force of taonga depends not on techniques of animation but on the living transmission of cultural knowledge and values"; what matters is "the vitality, the survival, of those for whom these objects are taonga," but also that "intangible cultural property . . . must be performed to be transmitted" (Kirshenblatt-Gimblett I998, I66).

Central to determining the fate of whare and fale overseas are the relationships that cluster around them. As the relationships between houses, communities of origin, and caretakers change, so do the houses' functions and forms, and their respective roles can rapidly oscillate between different perceptions. Hinemihi is at one and the same time a building or object to some, an icon or beacon of identity to others, or a representation of the global existence of Māori; to those connected to her through whakapapa (genealogy), she "embodies their history and future" (Wikitera 20I 5, 6). "Culture and identity as performative acts" can be safely articulated in this "contact zone" under the care and control of Hinemihi's people, and "the making and remaking of identities" can take place while "stasis and purity are asserted—creatively and violently-against historical forces of movement and contamination" (Clifford I997, 7). Thus, as Māori tikanga (correct procedure), kawa (formal marae protocols), and ritenga (customs, practices or rituals) are enacted at Hinemihi, they are also modified to fit her contemporary environment (Wikitera 20I5, 6). To outsider visitors, 
for whom a range of signals may fail to add up to a coherent picture, it may not be visible that Hinemihi has retained much of the potentiality of a marae (Wikitera 201 5, 249, 6). For outsiders, the full picture of a house's travels may only become recognizable in hindsight.

Mataatua, for instance, traveled to Australia, England, and back to New Zealand as an ethnographic artifact and national icon of sorts. The house was then "restored" as an item of national cultural heritage at the Otago Museum. This restoration entailed, however, a cutting short of the house so that it would fit into the museum building; some panels were even replaced with panels from other tribal areas (Allen I998, I 5I). Yet, when the house finally returned home to Whakatāne in I996, it did so as a taonga and became the core of a tribal cultural center opened in $20 \mathrm{II}$. As for Hinemihi, the UK National Trust currently works with Māori to ensure that future developments respect the whare's cultural and conservational authenticity. Thus, the capacity of contemporary Māori "to identify with, celebrate, and reclaim taonga fosters not despair but a sense of hope" (Thomas 2009, I72). New perspectives (or partitions in Benjamin's sense) arise from the collaborations between European institutions and the houses' communities of origin, and an understanding grows that looking after taonga includes actively maintaining relationships with their spiritual owners (see Engels-Schwarzpaul and Wikitera 2009b). ${ }^{16}$

This agenda seems far less developed in the case of Samoan fale, which are normally produced for venues outside of Sāmoa as business concerns. Yet, underneath or among the apparent financial motifs, there is still a sense of what is right and wrong in the use of fale, based on the connection between the houses and people-and the fact that the fale was originally consecrated would index this connection. Some Samoans Albert Refiti and I interviewed in Apia, who had themselves lived in Aotearoa for some time, referred to fale abroad in terms similar to those used by Māori, that is, as embodiments of Samoan culture and as ancestral beings endowed with a life force and the capacity to feel lonely in their locations overseas. The fale at Tropical Islands Resort, however, is located too far away from any Samoan community that could gather around it. Further, the sense of generative and mutual relationships that Samoans often express in regard to Germany, as the place of their own ancestors, is not shared by the resort's managers. This constellation is different in Lā'ie at the Polynesian Cultural Center, where the Samoan village community is apparently less closely knit than the Māori one, but where Samoans are nevertheless an integral part of the overall Pacific community working at the PCC. 
When, by internal or external force, those associated with a house fail to assemble, taonga and tūpuna (in Māori terms) may for a time turn into commodified, indiscriminately circulating objects. As long as they are cut loose from "their aura, their crown, their web of associations" (Latour 2004, 237) or, in Friedrich Nietzsche's terms, when they are deprived of the enveloping atmosphere all living things need, "condemned to revolve as a star without atmosphere," we should not "be surprised if they quickly wither and grow hard and unfruitful" (1997, 97). As Carl Mika has argued from a Māori perspective, there are affinities and solutions, particularly with some less central modes of Western thought, that "encourage thought towards an approximation of a thing in all its complexity and its interdependence with all other things, including the self" $\left(20 \mathrm{I}_{5}, 6\right)$. According to Bruno Latour, an object is "simply a gathering that has failed"-it has "not been assembled according to due process" $(2004,246)$. Fale become objects when they lack the participants and associations that make them exist as things and maintain their existence; as long as the houses are held in relational webs, however, they are, even as commodities, "matters of concern" $(2004,237)$. As long as the houses gather people around them, they do not drift arbitrarily-they are, as matters of concern, open and relational. In that sense, while themselves held in place by human and nonhuman relationships, houses can, in turn, gather many participants and hold them firmly in place. ${ }^{17}$ They bind human engagements to a relationally structured space of here and now. And just as the houses' status can change in different directions with changing relationships, people's gatherings, too, are affected by their houses' state.

Hinemihi, in particular, demonstrates that a house's relational web can include diverse components: the source community, local Māori expats, individuals and institutions in the diaspora, and even, on occasion, the general public. What is developed in this dynamic constellation has implications that go beyond the situation in Clandon Park: as Wikitera has noted, it shows that "Māori spaces are not confined to geographical places" but can be shaped by new social factors and notions of cultural identity. These factors, in turn, reflect changes in Māori society, such that Māori are now a "predominantly diasporic people," in Aotearoa and abroad; most of them are born to be travelers and to live away from their tribal tūrangawaewae so that, of necessity, they develop "'kaupapa based" identities outside of tribally determined criteria of place" (Wikitera 20I 5 , 238). For this, they need spaces in which these identities are both secure and open to new dimensions, where Māori "can be Māori regardless of 
historical trauma, dislocation and disconnect from tribal relationships." The additional layers brought to the processes involving tikanga, kawa, and ritenga "do not impugn the others but, rather, provide a third space in which all those who are connected to Hinemihi can come together" (Wikitera 20I 5, 239).

If the development and maintenance of wharenui as a community concern was a response at the level of the hapū (grouping of whānau, or extended families) to colonial change in Aotearoa (see Rosenblatt 2003, 39), then perhaps the communal management of houses located overseas is a corresponding maintenance or performance of identity in a globalized and so-called postcolonial world. Rosenblatt has attributed the ability of houses to serve a unifying role-and to give Māori a collective identity independent of the state- to the complexity of their symbolic structure and the various, complex ways in which they are performative. ${ }^{18}$

\section{A Secret Agreement}

To an extent, encounters between strangers are determined in advance by their social and cultural backgrounds. Interest and fascination with foreigners, or an ambivalence between curiosity and fear, is often terminated by the impulse to control the strange. ${ }^{19}$ In fact, "culture" first arises in the confrontation with the foreign; it is the product of changes caused by adaptation to unknown conditions involving the exchange with strangers. Once involved, our boundaries start to shift and we must change (Erdheim I992, 734). ${ }^{20}$ This change is likely to displace the angle of vision so that a new partition in one's individual but also one's culturally shared historical perception is created. This new partition can bring a fresh, positive element to the fore, creating a perspective wherein qualities that might have seemed unproductive, retrograde, and obsolescent in the past (in contrast with qualities then considered positive) might now, and in the future, be considered lively and positive. In an ongoing process of one's own world confronting others, more and more of what was disregarded in the past can become part of a generative and permanent historical restitution (Benjamin I999, 459 [NIa,3]). The "displacement of the angle of vision" required to do this becomes feasible when unknown positions are taken up, if only experimentally. That is, if the angle of vision emanates from the Pacific, different relationships between past and present, people and houses may become visible for European museums holding taonga since the last century. ${ }^{21}$ In the case of Sāmoa and Germany, given their 
genealogical ties, this is also about a restitution of historical relationships. Benjamin has argued that this is possible. He concluded the second of his theses on the concept of history with the statement that the current generation has "a weak Messianic power, a power to which the past has a claim. That claim cannot be settled cheaply. . . nothing that has ever happened should be regarded as lost for history" (Benjamin I969a, 254).

Another form of partition would be required to redeem the past in places like the Tropical Islands Resort, where the fale was properly commissioned but not properly maintained. What kind of displacement might be possible, however, so long as theme parks (today's Völkerschauen in many respects) insert "exotic" cultures principally into binary schemes of difference, safely displacing the past into some ethnological eternity, unspoilt earthly paradise, or Eden? ${ }^{22}$

The Pacific houses remaining on show in Europe can be catalysts for the development of new ways of thinking and relating. They suggest Benjamin's notion of a "secret agreement" between past and present generations, by which the past has a claim to redemption in our present (I969a, 254) in order to bring a different past (and with it new possibilities of relationships) into being. Forgotten and ignored in Europe, perhaps, but not lost for history, the relationships between Europe and the Pacific initiated during colonization persist. While, in their current locations, Pacific houses overseas may have lost their ancient function as local communities' daily companions, they still have a critical power and potential to shape and shelter new types of relationships in present diasporic contexts, often precisely by indexing their ambivalent nature. What factors determine how mutual Pacific-European relationships can be and under what conditions Pacific houses can create and aggregate relationships in the European diaspora? Certainly, as contemporary Pacific people travel globally, wayfinding — an old Pacific navigators' art—increasingly involves navigating diasporic connections and (per)forming new types of spaces, relationships, and identities. Māori and Pacific people create Māori and Pacific spaces in Alice Springs, Auckland, London, San Francisco, Sydney, and many other places in the world. From their performances of diasporic relationships may emerge a reconfiguration of the place and meaning of traveling houses from Pacific homelands into new lands. The new partitions they produce in the field of perception, regarding both the historical and the contemporary, will have ramifications and potentials for global relationships beyond those between Māori and British and between Samoan and German people. 


\section{Notes}

I For houses outside scenic spaces in the diaspora, see also, eg, the video At Home While Away (Fitch and Hezel 2015) at 45:I4 mins.

2 These perspectives include Benjamin I999; Durie 2000; Engels-Schwarzpaul and Wikitera 2009a, 2009b; MacCannell I992, 2008; Mead 2003; Refiti 2015; Sully 2007; Sully, Raymond, and Hoete 20I4; Thode-Arora and Hempenstall 20I4; Tui Atua 2008; and Wikitera 2015.

3 See also Wikitera 20I 5, 267, for a discussion of whakapapa korero (tribal narrative, kin-based ways of cultural knowledge transmission) as further engaged by writers like Paul Tapsell (2002, 20I2) and Ngarino Ellis (20I2).

4 Members of Rauru's source community differ in their assessment of his future: "Te Poroa Malcolm, a Te Awara elder, believes Rauru needs to return to NZ, he appreciates the care the museum has given Rauru but 'it still falls far short of where he should be, that is with his people'" (Parahi 20I 2, 5:1 5-5:47 mins).

5 See Christopher Balme’s observations (I998, 64), which still seem pertinent in this respect.

6 The first recorded visit by an official party occurred in I986, though there may have possibly been an earlier one, before Mead's visit in I984 (Hilke ThodeArora, pers comm, June 20I 5). A delegation from the "New Zealand Māori Arts and Crafts Institute" included Emily Schuster, a descendant of Tene Waitere and mother of Jim Schuster.

7 During the extended collaboration with Jim and Catherine Schuster, as well as Te Arawa and other Māori participants in the "Rauru Project," both Köpke and Kokott were surprised about the frankness that was possible and the emphasis on the whānau (extended family) principle. Köpke and Kokott understand that, through their extended relationship with Rauru, they have become part of Te Arawa history. The "ancestors" now in Hamburg are now also their "responsibility" to look after, together with Te Arawa: "We must make sure that, for the next one hundred years, the meeting house continues to be well looked after and does not feel lonely again, and that the contact with the Te Arawa people will not be broken" (Köpke 20I2, I7).

8 The term "ambassador" was then used in reference to Hinemihi by Dean Sully, Allan Gallop, and Karl Burrows in Decolonising Conservation (Sully 2007; see also the use of the term on the Te Maru o Hinemihi website, quoted in the next section) and adopted by Te Kenehi Teira, Head of the Māori Department at the Historic Places Trust in Aotearoa, when he told Köpke that he regards Rauru as an "ambassador of the Te Arawa people, and of Māori culture in Europe overall” (quoted in Köpke 20I2, I8).

9 Ranginui Walker counted more than 200 instances of the word "house" 
in nineteenth-century New Zealand Governor George Grey's Nga Mahi $\bar{a}$ Ngā Tüpuna (1928) and more than 70 in the memoirs of Nepia Pohuhu, which seems to indicate the importance of houses in Te Ao Māori, the Māori world (Bennett 2007, 39).

Io Memorandum Secretary, Department of External Affairs to Secretary, Samoan Administration, 25 May 1923; Memorandum Secretary, External Affairs, for His Excellency, Administrator of Western Samoa, 25 January I923; both IT I EX 87/20, Archives New Zealand, Te Rua Mahara o te Kāwanatanga, Wellington.

II In some photos, the pola are mounted upside down (eg, Hamburg Museum für Völkerkunde archive, Iconokarte $\mathrm{Nr}$ I 5-6, Polynesien-Samoa Samoa_4_80 and Samoa_4_8 I, I900, source: Zoolog. Garten, Hamburg). In From Samoa with Love?, a photo of a west Sudanese exhibition, Futa, by the same impresarios, the Marquardt brothers, suggests that the roofs of all their "exotic" exhibitions might have been thatched with the same material (compare Thode-Arora and Hempenstall 20I4, 73, I22, and 2I).

I 2 In the first, straw huts are surrounded by palm trees and two women in the background, with lei around their necks and heads, are naked apart from their grass skirts (Dreesbach 20I2, I4O-I4I). Another poster, Der Wasserrutsch vom hohen Felsen (Kroeber-Wolf and Mesenhöller 1998, 387), combines a photo of the heads of contemporary Samoan women swimming in a pool (probably at Papase'ea Sliding Rocks in Sāmoa) with a drawing of women sliding down "Papase'ea rock" during the exhibition. In the painted part, the women are naked from the waist up—an unlikely scenario in Sāmoa in I9Io. A woman in the foreground of the poster (wearing only lei and grass skirt) is shown half turned toward the spectator, beckoning with a sweet smile and pointing to her friends in the waterfall. These examples of "native life" disregarded contemporary historical and social conditions in the Pacific and staged an appearance of the strangely familiar, onto which fantasies of the foreign and familiar could be projected.

I3 Many, but not all, wharenui are named after specific ancestors and are then called whare tūpuna or whare tipuna (Brown 20I4).

I4 A growing realization of the blind spots in all cultures, including one's own (Baecker 20I2, 70, I09), affects notions of control and ownership in museum practices and impacts, for instance, on the ways in which Hinemihi and Rauru are regarded by their keepers: even though there is still a long way to go toward a genuine partnership, ownership of objects and stories is beginning to be shared (see Gurian I999, I76, I8I).

I 5 As a "National Trust property, a Grade II Listed Building," she is also a registered specimen in a collection of historic buildings.

I6 Latour's notion of assembling as a critical act (2004) implies that objects 
can become taonga again when sufficiently adequate relationships arise to hold them in place. In fact, this is what can be observed with some of the Māori wharenui that remain overseas. Thus, the possibility of multidirectional change (and potentially counter-directional change from different perspectives) points to the important and ongoing work of maintenance and care, and specifically to the balances of power in such processes. Wikitera's $\mathrm{PhD}$ thesis closes with a poroporoaki, an expression of grief: after a fire, the Clandon mansion opposite Hinemihi was severely damaged. Hinemihi survived another tragedy despite her closeness to the fire, but her future is uncertain again as the delicate web of relationships among her people has been disturbed by the event.

I7 It is now recognized in conservation theory and practice in Europe and the United States that looking after taonga includes actively maintaining relationships with their spiritual owners. “'Keeping the taonga warm,' from a Māori point of view, means re-establishing links with Māori people where they have been broken, and by so doing, helping to conserve the essence . . . of the taonga themselves" (Terrell, Wisse, and Philipp 2007, 96).

I 8 The relationship between descent group and house, or that between the name and the ancestor carved on it, constitutes "the relations it represents as much as it is determined by them" (Rosenblatt 2003, 229).

I9 This prevents the "con-fusion" of the foreign and the familiar, which would make the familiar seem strange and the strange like one's own-a fundamental condition for cultural innovation that gives cultural identity a life-affirming tension (Erdheim 2002, 29). The antagonisms often inherent in ambivalence forcefully keep our spirits alive and reaching out beyond our space and time, our environment and history (Erdheim I992, 737, 743).

20 In contrast with the concept of the Other, that of the stranger refers to all those things that do not belong to us yet somehow concern us in specific ways (Erdheim I992, 734). The strange is always already there, yet it cannot be understood from the outside (Yousefi 2008, 43).

2 I In this context, a two-day symposium titled "Curatopia: Histories, Theories, Practices; Museums and the Future of Curatorship," held in Munich 6-7 July 20I 5, was interesting, given that about a third of the presenters were from the Pacific.

22 Would it be realistic to expect the visitors of theme parks to be interested in the memory of the colonial past shared with Samoans and in conversations about sharing a present and future? At the same time as Pacific people call on the power of ideas, bodies, rituals, and performance to create relational spaces on their own terms, their cultures are, in an exponentially growing global commodification of indigenous cultures, deployed to stimulate Western consumers' imagination and desires. While Pacific people on the whole invest in continuous relationships even in contemporary entertainment contexts, Western systems of governance and trade do not support such investments. 
References

Allen, Ngapine

I998 Maori Vision and the Imperialist Gaze. In Colonialism and the Object: Empire, Material Culture, and the Museum, edited by Tim Barringer and Tom Flynn, I44-I 52. London: Routledge.

Baecker, Dirk

2012 Wozu Kultur? [Why Culture?] Berlin: Kadmos.

Balme, Christopher B

I998 Staging the Pacific: Framing Authenticity in Performances for Tourists at the Polynesian Cultural Center. In Theatre, Diaspora, and the Politics of Home, a special issue of Theatre Journal 50 (I): 53-70.

Benjamin, Walter

I969a Theses on the Philosophy of History. In Illuminations: Essays and Reflections, edited by Hannah Arendt, 253-264. Translated by Harry Zohn. New York: Schocken Books. Original edition, I940, Suhrkamp Verlag.

I969b The Work of Art in the Age of Mechanical Reproduction. In Illuminations, edited by Hannah Arendt, 217-25I. New York: Schocken.

I999 The Arcades Project. Translated by Howard Eiland and Kevin McLaughlin. Cambridge, ma: Harvard University Press.

Bennett, Adrian John Te Piki Kotuku

2007 Marae: A Whakapapa of the Maori Marae. PhD thesis, Māori Studies, University of Canterbury, Christchurch.

Brown, Deidre

2OI4 Māori Architecture-Whare Māori: Ancestral and Mythological Origins. In Te Ara, the Encyclopedia of New Zealand, updated I4 Oct 20I4. http://www.TeAra.govt.nz/en/maori-architecture-whare -maori/page-2 [accessed 8 July 20I6]

Clifford, James

I997 Routes: Travel and Translation in the Late Twentieth Century. Cambridge, MA: Harvard University Press.

Dreesbach, Anne

2012 Kolonialausstellungen, Völkerschauen und die Zurschaustellung des "Fremden" [Colonial Exhibitions, Ethnographic Shows and the Exhibition of the "Strange"]. Europäische Geschichte Online (EGO), I7 Feb. http://www.ieg-ego.eu/dreesbacha-20I2-de [accessed 8 July 2016]

Durie, Eddie

2000 Te Hono ki Hawai'iki: The Bond with the Pacific. In Culture, Rights, and Cultural Rights: Perspectives from the South Pacific, edited by Margaret Wilson and Paul Hunt, 47-55. Wellington: Huia. 
Ellis, Ngarino

2012 "No Hea Koe? Where Are You From?” Māori Meeting Houses Overseas. In The House Rauru: Masterpiece of the Māori, edited by Bernd Schmelz and Wulf Köpke, 4I9-435. Mitteilungsband 44. Hamburg, Germany: Museum für Völkerkunde.

Engels-Schwarzpaul, A-Chr, and Keri-Anne Wikitera

2009a Counter Currents: Whare Nui and Fale Abroad. Paper read at "The Pacific Connection: Trade, Travel and Technology Transfer" conference, University of Melbourne, I9-22 Feb. http://aut .researchgateway.ac.nz/handle/I0292/2996 [accessed 6 July 20I6]

2009b Take Me Away ... In Search of Original Dwelling. In Adam's House in Paradise, edited by Ross Jenner, Mark Jackson, and A-Chr EngelsSchwarzpaul. Special issue of Interstices: Journal of Architecture and Related Arts I0:42-54. http://interstices.aut.ac.nz/ijara/index.php/ Erdheim, Mario ijara/article/view/I66 [accessed 8 July 20I6]

I992 Das Eigene und das Fremde: Über ethnische Identität [Native and Alien: On Ethnic Identity]. Psyche: Zeitschrift für Psychoanalyse und ibre Anwendungen 46 (8): 730-744.

2002 Verzerrungen des Fremden in der psychoanalytischen Perspektive [Distortions of the Strange from a Psychoanalytical Perspective]. In Fremde: Freiburger literaturpsychologische Gespräche; Jahrbuch für Literatur und Psychoanalyse Bd, edited by Ortrud Gutjahr, 2I-45. Würzburg: Königshausen \& Neumann.

Fitch, Nathan, and Francis X Hezel

20I5 At Home While Away. Online video, 55 minutes. http://www. athomewhileaway.org/ [accessed 8 July 2016]

Frazon, Zsófia

2016 New Museology. In Curatorial Dictionary, edited by Eszter Szakács. http://tranzit.org/curatorialdictionary/index.php/dictionary/new

Grey, George -museology/ [accessed 8 July 2016]

I928 Ngā Mahi à Ngā Tūpuna. New Plymouth, NZ: T Avery \& Sons, Ltd. Gurian, Elaine Heumann

I999 What Is the Object of This Exercise? A Meandering Exploration of the Many Meanings of Objects in Museums. Daedalus I 28 (3): I63I 83 .

Jonassohn, Kurt

200I On a Neglected Aspect of Western Racism. Paper presented at a meeting of the Association of Genocide Scholars, Minneapolis, 9-I 2 June. Published in the Occasional Papers Series of the Montreal Institute for Genocide and Human Rights Studies (MIGS), Concordia 
University, 23 April 2015, and available online via http://spectrum. library.concordia.ca/979954/ [accessed 3 Aug 20I6]

Kirshenblatt-Gimblett, Barbara

I998 Destination Culture: Tourism, Museums, and Heritage. Berkeley: University of California Press.

Kokott, Jeanette

2012 One Hundred Years of Rauru in Hamburg: Building Bridges between Aotearoa/New Zealand and Germany. In The House Rauru: Masterpiece of the Māori, edited by Bernd Schmelz and Wulf Köpke, 26-37. Köpke, Wulf

Mitteilungsband 44. Hamburg, Germany: Museum für Völkerkunde.

2012 More than Just a Meeting House . . In The House Rauru: Masterpiece of the Māori, edited by Bernd Schmelz and Wulf Köpke, I3-25. Mitteilungsband 44. Hamburg, Germany: Museum für Völkerkunde.

Kroeber-Wolf, Gerda, and Peter Mesenhöller

I998 Talofa! Samoa, Südsee: Ansichten und Einsichten. Frankfurt, Germany: Museum für Völkerkunde.

Latour, Bruno

2004 Why Has Critique Run Out of Steam? From Matters of Fact to Matters of Concern. Critical Inquiry 30 (2): 225-248.

MacCannell, Dean

I989 Staged Authenticity. In The Tourist: A New Theory of the Leisure Class, 9I-I08. New York: Schocken.

I992 Empty Meeting Grounds: The Tourist Papers. London: Routledge.

2008 Why It Never Really Was about Authenticity. Society 45 (4): 334337.

Mane-Wheoki, Jonathan N

I993 Mataatua: No Wai Tenei Whare Tupuna? A Report on Ngati Awa Claim (Wai 46) Commissioned by the Waitangi Tribunal, Wellington.

Mead, Hirini Moko

2003 Tikanga Maori: Living by Maori Values. Wellington: Huia Publishers.

Mika, Carl

2015 Counter-Colonial and Philosophical Claims: An Indigenous Observation of Western Philosophy. In Blind, or Keenly Self-Regarding? The Dilemma of Western Philosophy, edited by Carl Mika and Michael Peters. Educational Philosophy and Theory 47 (II): I I36-II 42.

Nietzsche, Friedrich

I997 Untimely Meditations. Edited by Daniel Breazeale. Translated by R J Hollingdale. Cambridge, uk: Cambridge University Press. 
Parahi, Carmen

2012 Rāuru Wharenui Celebrates Ioo Years. Video, 8.5 minutes. maraetv, published on YouTube I2 Nov. https://www.youtube.com/watch ?v=dHG47c5ViHI [accessed 8 July 20I6]

Raymond, Rosanna, and Dean Sully

20I0 Sharing with Hinemihi. http://www.hinemihi.co.uk/media/I 2 I 2 Io -I 230-Sharing\% 20With\% 20Hinemihi\% 2ohandout.pdf [accessed 8 July 20I6]

Refiti, Lealiifano Albert L

2015 Mavae and Tofiga: Spatial Exposition of the Samoan Cosmogony and Architecture. PhD thesis, Art and Design, Auckland University of Technology.

Rosenblatt, Daniel

2003 Houses and Hopes: Urban Marae and the Indigenization of Modernity in New Zealand. PhD thesis, Anthropology, University of Chicago.

Samoa Times and South Sea Advertiser

I893 Local and General News, I April. Samoa Times and South Sea Advertiser 5 (I39): 2. Archived at http://paperspast.natlib.govt.nz/ cgi-bin/paperspast? $\mathrm{a}=\mathrm{d} \& \mathrm{~d}=$ STSSA $18930401.2 .6 \& \mathrm{cl}=$ search \&srpos

Sully, Dean, editor $=3$ \&e=-------IO-STSSA-I----omoors- [accessed 8 July 2016]

2007 Decolonising Conservation: Caring for Maori Meeting Houses Outside New Zealand. Walnut Creek, CA: Left Coast Press.

Sully, Dean, Rosanna Raymond, and Anthony Hoete

20I4 Locating Hinemihi's People. Journal of Material Culture I9 (2): 209-229.

Tapsell, Paul

I997 The Flight of Pareraututu: An Investigation of Taonga from a Tribal Perspective. The Journal of the Polynesian Society 106 (4):323-374.

2002 Marae and Tribal Identity in Urban Aotearoa/New Zealand. Pacific Studies 25 (I): I4 I-I7I.

20I2 Rauru and the Genesis of Ngā Whare Wānanga o Te Arawa. In The House Rauru: Masterpiece of the Mãori, edited by Bernd Schmelz and Wulf Köpke, 87-II3. Mitteilungsband 44. Hamburg, Germany: Museum für Völkerkunde.

Te Maru O Hinemihi

2016 About Us: Te Maru O Hinemihi. http://www.hinemihi.co.uk/page .php?id=24 [accessed 8 July 2016]

Terrell, John Edward, Désirée C J Wisse, and Christopher J Philipp

2007 Ruatepupuke II, The Field Museum, Chicago: The Past and Possible 
Futures. In Decolonising Conservation: Caring for Maori Meeting Houses Outside New Zealand, edited by Dean Sully, 89-109. Walnut Creek, CA: Left Coast Press.

Thode-Arora, Hilke, and Peter Hempenstall, editors

20I4 From Samoa With Love? Samoan Travellers in Germany I895I9I I: Retracing the Footsteps. Museum Fünf Kontinente exhibition catalog. Translated by Bram Opstelten and Michael Jane. Munich, Germany: Hirmer.

Thomas, Nicholas

2009 Rauru: Tene Waitere, Māori Carving, Colonial History. Photographs by Mark Adams. Dunedin: Otago University Press.

Triesch, Carl

20I2 From Rotorua to Hamburg: Rauru Finds a New Home. In The House Rauru: Masterpiece of the Māori, edited by Bernd Schmelz and Wulf Köpke, 292-223. Mitteilungsband 44. Hamburg, Germany: Museum für Völkerkunde.

Tui Atua

2008 Resident, Residence, Residency in Samoan Custom. In Su'esu'e Manogi: In Search of Fragrance; Tui Atua Tupua Tamasese Ta'isi and the Samoan Indigenous Reference, edited by Tamasa'ilau Suaalii-Sauni, I'uongafa Tuagalu, Tofilau Nina Kirifi-Alai, and Naomi Fuamatu, 93-I03. Apia: The Centre for Samoan Studies.

von Mangoldt, Beatrice, and Stefanie Gromes

20I3 7 Tage ... deutsche Tropen. Episode of documentary series 7 Tage, 22 Sept. Produced by NDR Germany.

Wikitera, Keri-Anne

2015 Māori Spaces in Foreign Places: Hinemihi o Te Ao Tawhito. PhD thesis, School of Hospitality and Tourism, Auckland University of Technology.

Wineera, Vernice

2000 Selves and Others: A Study of Reflexivity and the Representation of Culture in Touristic Display at the Polynesian Cultural Center, Laie, Hawaii. PhD thesis, American Studies, University of Hawai'iMānoa.

Yousefi, Hamid Reza

2008 Phänomenologie des Eigenen und des Fremden [Phenomenology of Own and Other]. In Wege zur Kultur. Gemeinsamkeiten - Differenzen - Interdisziplinäre Dimensionen, edited by Klaus Fischer, Ina Braun, and Peter Gerdsen, 25-52. Nordhausen, Germany: Traugott Bautz. 


\section{Abstract}

The paper explores the mutual impact of Pacific houses and people in diasporic relationships. Tracing the fates of several whare and fale now located in Europe, it explores changes over time that resulted from different degrees of closeness or distance between the people gathered around them. Three houses feature prominently in the paper: Hinemihi o te Ao Tawhito in Clandon Park (close to London, UK); Rauru at the Museum für Völkerkunde (Hamburg, Germany); and a fale from Apia at the Tropical Islands Resort (close to Berlin, Germany). They enjoy and have historically enjoyed different degrees of connection with their source communities, which, I suggest, directly impact their role and state of being in their current locations. What their stories show is that identities and angles of vision change in particular ways during processes of colonization and globalization. These changes are relevant for local and global cultural developments and their role in cultural tourism, but also for the consideration of global identities generally. Together, Pacific notions of generative (rather than objectifying) relationships between people, and Benjamin's notion of a performative relationship between present and past opening new angles and future possibilities, suggest that present and past relationships can be redeemed.

KEYWORDS: globalization and cultural change, spatial practices, indigenous knowledge, Pacific Island studies, postcolonial studies, museum studies, tourism 